Maximilian von Zedtwitz, Oliver Gassmann, and Roman Boutellier (2004)

\title{
ORGANIZING GLOBAL R\&D: CHALLENGES AND DILEMMAS
}

The final version of this manuscript is published in Journal of International Management, 10(1): 21-49.

The final publication is available at www.sciencedirect.com:

http://www.sciencedirect.com/science/article/pii/S1075425303000954/pdfft?md5=2fc 574fe72b490f79acacd9d1df1 1f27\&pid=1-s2.0-S1075425303000954-main.pdf DOI: $10.1016 /$ j.intman.2003.12.003

http://dx.doi.org/10.1016/j.intman.2003.12.003

Please note that differences between this manuscript and the final publication may exist. In case of questions, please contact the corresponding author as indicated below. 


\title{
ORGANIZING GLOBAL R\&D: CHALLENGES AND DILEMMAS
}

\author{
Maximilian von Zedtwitz \\ Professor of Technology Management, IMD - International \\ P.O. Box 915, CH-1001 Lausanne, Switzerland \\ zedtwitz@imd.ch \\ Oliver Gassmann \\ Professor of Technology Management, University of St. Gallen, \\ Institute of Technology Management \\ Unterstrasse 16, CH-9000 St. Gallen, Switzerland \\ oliver.gassmann@unisg.ch \\ Roman Boutellier \\ Adjunct Professor, University of St. Gallen, and \\ CEO Schweizerische Industrie-Gesellschaft (SIG) \\ CH-8212 Neuhausen, Switzerland \\ roman.boutellier@unisg.ch
}

\begin{abstract}
After more than a decade of widespread global R\&D expansion, top managers in multinational companies take decentralized competencies for granted, expecting their international research and product development functions to deliver results. However, based on more than 150 in-depth interviews and case research carried out with 18 multinational companies from three industry groups between 1996 and 2000, we have identified six fundamental dilemmas that make it difficult even for companies with carefully managed distributed R\&D networks to exploit the full potential of global innovation. In addition to a root-problem analysis, we surveyed these companies about the drivers of R\&D globalization, and how these drivers would affect their organizations over the next ten years. Although some of the trends that emerged are industry-specific with regard to technology development, we describe five common traits that are expected to shape $R \& D$ organization in the mid-term future.
\end{abstract}

\section{Keywords}

Globalization, international innovation, R\&D organization, project management, knowledge management 


\section{Introduction}

Research and development - and as a result technology—have tremendously improved the quality of human life over the last five decades. With the increasing significance of technology today, it becomes apparent that R\&D has to take into account not only customers and business economics but the environment and society as well. DuPont's mission statement "Better things for better living through chemistry" tries to capture this spirit. Kao's mission of "Safety for society and users" includes the all-important customer in its vision. It is difficult enough to find an all-encompassing vision that appeals to customers, employees and investors with different values and expectations. It is perhaps even more difficult to execute this vision. What are the challenges for $\mathrm{R} \& \mathrm{D}$ that result from considering economical, ecological and societal issues in an increasingly connected world?

\section{The Global R\&D Management Agenda}

Most R\&D configurations are the result of mergers, acquisitions and manufacturing-location decisions. Criteria for what constitutes a good location or a good R\&D environment have changed over time. Therefore, many multinational companies have set up R\&D locations for reasons that no longer apply. For example, cheap shop labor in Singapore evolved into fullyfledged R\&D centers (inconceivable in the 1950s or 1960s), strong biotechnical research at Cambridge University has attracted pharmaceutical companies to establish R\&D centers nearby; and since the 1990s R\&D centers have moved to emerging markets in Southeast Asia, India, and China.

But by the end of the 20th century, "more and more of the human work [became the] work of thought and communication" (Simon, 1997: 238). Metal basher criteria, inexpensive labor and the proximity of development units to target markets lost in importance compared to trends that mainly emerged in the last decade: concentration on core capabilities, global R\&D outsourcing R\&D, the "hunt for talent," information and communication technology (ICT) facilitating improved decision making in networks, or mobile resource allocation to divisions, corporate labs and regions, to name just a few. Table 1 enumerates major challenges of R\&D globalization that were revealed in our research with 18 multinational companies.

Table 1. What are the major challenges and issues for managing global R\&D at your company?

\begin{tabular}{|c|c|}
\hline Company & Challenges and Issues for Managing Global R\&D \\
\hline DuPont & $\begin{array}{l}\text { Impact of information technology; virtual organizations; } \\
\text { - Structure versus processes in R\&D; } \\
\text { - Access to new sciences and technologies from the home base. }\end{array}$ \\
\hline Roche & $\begin{array}{l}\text { - Increasing R\&D costs; } \\
\text { - Cost containment in public health care; } \\
\text { - Availability of genomics data. }\end{array}$ \\
\hline Schering & $\begin{array}{l}\text { - Globalization of regulatory environment; } \\
\text { - Competition for innovation through new enabling technologies; } \\
\text { management; }\end{array}$ \\
\hline Ciba & $\begin{array}{l}\text { - Country selection for global project responsibility; } \\
\text { - Coordination and exploitation of synergy between distributed R\&D centers; } \\
\text { - } \quad \text { Aggrification and use of third party research centers; } \\
\text { - }\end{array}$ \\
\hline Nestlé & $\begin{array}{l}\text { Realize synergies between decentralized R\&D competence centers; } \\
\text { - Link research with business development; }\end{array}$ \\
\hline
\end{tabular}




\begin{tabular}{|c|c|}
\hline Као & $\begin{array}{l}\text { - Strong connection to the headquarters and laboratories in Japan; } \\
\text { - International R\&D strategy meetings. }\end{array}$ \\
\hline Xerox & $\begin{array}{l}\text { - Adapting R\&D management to a worldwide extended enterprise; } \\
\text { - Adequately trained human resource in systems and software; } \\
\text { communications. }\end{array}$ \\
\hline Canon & $\begin{array}{l}\text { - Global project set-up and optimal resource allocation; } \\
\text { - Making R\&D fruits into the assets of the whole group; } \\
\text { - } \text { Innovation management in a distributed environment; } \\
\text { - Better coordination, collaboration, and communication. }\end{array}$ \\
\hline$H P$ & $\begin{array}{l}\text { - Recruiting the right people who strive for knowledge and capabilities; } \\
\text { - Establishing networks across businesses, partners, customers, and HP; } \\
\text { - Increase of mobilization speed. }\end{array}$ \\
\hline$I B M$ & $\begin{array}{l}\text { - Creating the most advanced information technologies; } \\
\text { - Helping customers to apply technology to improve what and how they do it. }\end{array}$ \\
\hline$S \boldsymbol{A P}$ & $\begin{array}{l}\text { Efficient reconciliation and decision processes; } \\
\text { - Knowledge transfer between different sites; } \\
\text { - Process (customer to SAP) and Roll-Out (SAP to customer) processes; } \\
\text { Pronts. }\end{array}$ \\
\hline Unisys & $\begin{array}{l}\text { - Requirements and constraints of European Union to do business; } \\
\text { - Worldwide technology and business climate and market requirements; } \\
\text { - Setworks and tools to connect virtual offices to R\&D centers; } \\
\text { - Supply of skilled work force. }\end{array}$ \\
\hline$\overline{A B B}$ & $\begin{array}{l}\text { Business impact of innovative ideas and projects; } \\
\text { - } \text { Pew markets; } \\
\text { - } \text { Multinational/multicultural/cross-border teams. }\end{array}$ \\
\hline Daimler & $\begin{array}{l}\text { Soft and informal coordination means in transnational R\&D projects; } \\
\text { - } \text { Ovilding a global mind-set for R\&D employees; } \\
\text { duration; } \\
\text { - Overcoming interfunctional as well as geographical distances. }\end{array}$ \\
\hline Schindler & $\begin{array}{l}\text { - Systematic management of new technologies; } \\
\text { - } \text { Integration of decentralized technology and application knowledge; } \\
\text { - } \text { IT infrastructure and their role in concurrent engineering. }\end{array}$ \\
\hline Hitachi & $\begin{array}{l}\text { - Synergy in multi-dimension; } \\
\text { - } \text { Be prepared at competitive front-end of R\&D; } \\
\text { - } \text { Social role and responsibility becomes more global; } \\
\text { - Worldwide standardization of specifications and protocols. }\end{array}$ \\
\hline Leica & $\begin{array}{l}\text { - New technologies; } \\
\text { - Slobal market-driven strategies; } \\
\text { - Capable engineers. }\end{array}$ \\
\hline$M T U$ & $\begin{array}{l}\text { - Managing technology alliances on a global scale; } \\
\text { - } \text { Balancing market-/project orientation and innovation; } \\
\text { - Creating real international partnership. }\end{array}$ \\
\hline
\end{tabular}

All these challenges are about making decisions: How to set up structures, processes and support mechanisms to secure timely decisions with respect to new knowledge, new technologies, and new products. The basis for making these decisions-the framework for assessing benefits, risk, and costs-is complex, ambiguous, and non-trivial. Solutions are often the result of socio-political search processes that suffer from the bias of particular power groups, lack of timeliness and lack of system integration. 
The research leading to this paper was motivated by finding and describing some of the frameworks in order to make decision making for global innovation more transparent and effective. Based on case analysis and extensive research in three major industry groups, we aimed to make the following contributions:

- Ten challenges of managing global innovation;

- $\quad$ Six fundamental dilemmas in global R\&D;

- $\quad$ Five general trends that will affect R\&D management in the mid-term future.

The resulting paper is organized along those contributions. We conclude this paper with some suggestions and implications for improving the practice of global innovation management.

\section{$3 \quad$ Research Methodology}

The starting point for this research was our intention to study and learn from general global innovation practices in a variety of industries. Our research was conducted in three phases. The first phase lasted from 1994 to 1996 and focused on international R\&D organization and transnational R\&D project management. The second phase extended from 1996 to 1998 and focused on communication, coordination, and interface management in international R\&D. Both phases were conduced as explorative research and resulted in a fundamental understanding of global innovation; some of their findings have been published elsewhere (Gassmann, 1997; Boutellier, et al., 1998; Gassmann and von Zedtwitz, 1998 and 1999; von Zedtwitz and Gassmann, 2002a and 2002b).

The third phase was conducted between 1996 and 2000 and is the main focus of this contribution. This phase was separated into three parallel research efforts. First, we asked R\&D directors of 18 technology-intensive multinationals ${ }^{1}$ to compose in-depth case studies of their global R\&D structures and innovation processes. Each contribution was based on specific guidelines to allow comparison; it explained in detail what processes were at work, why they were in place, and what problems the organization faced in implementing innovation. Second, we surveyed these companies on additional data concerning R\&D performance and productivity, which we collected from the contributors of the case studies. Thus we had two complete perspectives (one qualitative, one more quantitative) on managing global R\&D operations in three industries: the pharmaceutical and health-care related industry, the electronics and software industry, and the electrical and machinery industry. Three of these companies have undergone dramatic changes in the meantime: Ciba merged with Sandoz to form Novartis, Daimler merged with Chrysler, and Hewlett-Packard spun of its measurement business into the independent company called Agilent.

Third - in addition to the 18 company cases-we conducted over 150 interviews on global R\&D management challenges with R\&D directors and chief technology officers from over 60 companies. We used a semi-structured interview guideline that reflected issues identified in phases 1 and 2. In some companies we were able to participate in workshops and $R \& D$ project meetings. Combined with internal documentation on $R \& D$ organization and technology strategy, presentations by senior R\&D personnel and memos from R\&D managers, these semi-structured data helped us to assess how these companies managed global R\&D. Finally, we reported our findings back to the interviewed companies and sought their feedback to correct erroneous interpretations and classifications (see Yin, 1994, for data triangulation and case study research).

Based on a combination of literature review and the input from the first two phases and the 18 case studies, we identified ten challenges and six fundamental dilemmas of managing global innovation.

\footnotetext{
${ }^{1}$ These companies were: ABB, Canon, Ciba, Daimler-Benz, DuPont, Hewlett-Packard, Hitachi, Hoffmann-La Roche, IBM, Kao, Leica, MTU, Nestlé, SAP, Schering, Schindler, Unisys, Xerox.
} 


\section{$4 \quad$ Ten Challenges for Managing Global Innovation}

One of the most important and pervasive insights is that managing innovation at the global scale is multi-dimensional. For instance, what are appropriate $R \& D$ structures for transnational innovation? What incentives must be given to increasingly sophisticated and increasingly mobile engineers? How are teams led that span various time zones, different languages and different organizations? In our research we first sought to identify those questions that posed the greatest challenges before we would go - in a second step - into any solutions or approaches that the company was taking to address these challenges.

As expected, there were no straightforward or easy answers for managing global innovation. We gained the impression that even leading companies were still in a state of experimentation with a number of sometimes contradictory approaches. We analyzed ten problem areas - or challenges - in more detail, identified interdependencies among them, and summarized the major currents and concepts that affect the management of $R \& D$ in multinational companies. Figure 1 depicts some of these issues in context. Because one of the challenges, "from function to integration," was omni-present in all considerations, it is not represented in this figure.

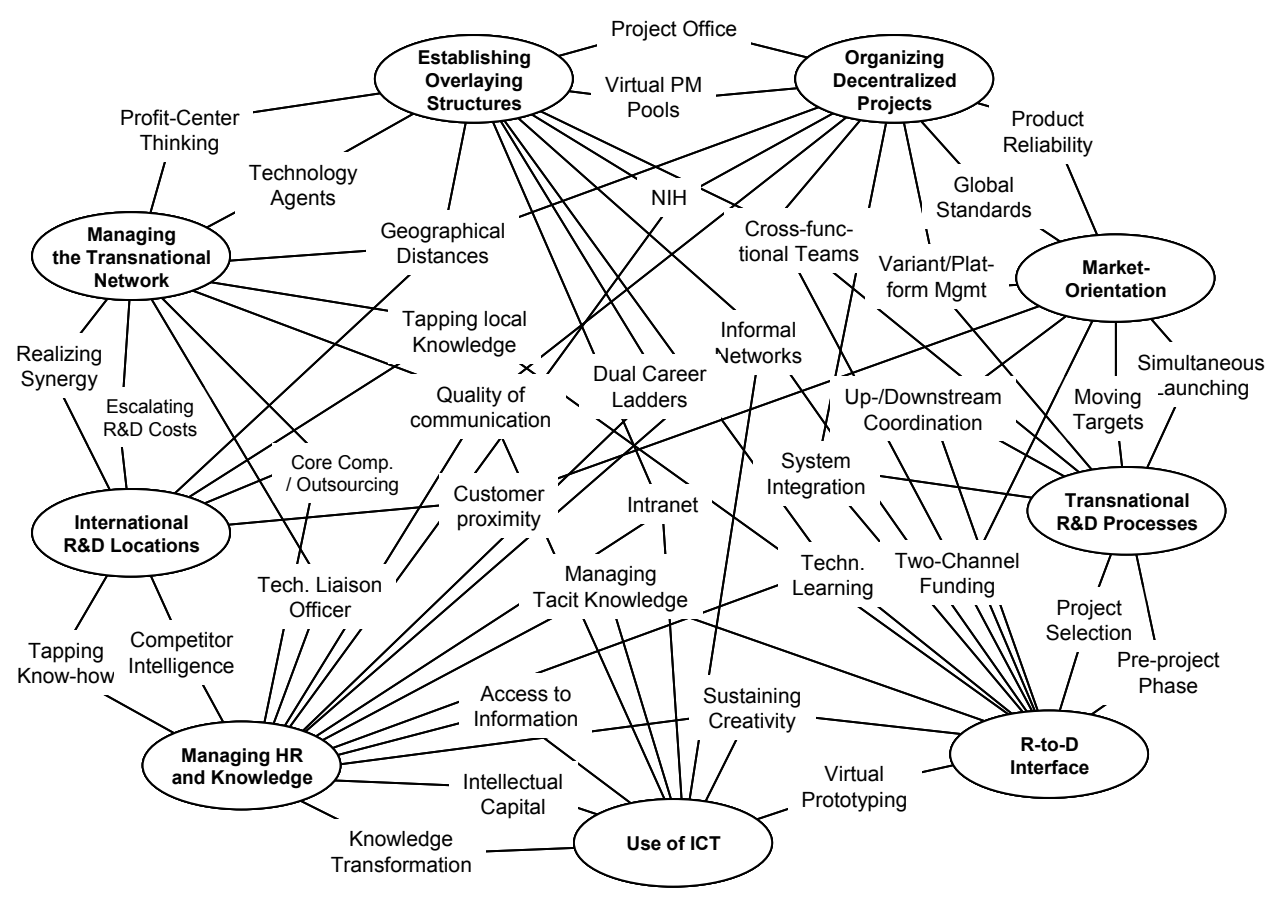

Fig. 1. Factors and main interdependencies influencing the management of global R\&D.

\subsection{From function to integration}

Originally, R\&D was organized as a highly specialized and separated corporate function. Due to productivity and transparency demands, R\&D began to be carried out in projects: Some form of matrix was needed to balance between scientific and engineering skills and team performance (e.g., Katz and Allen, 1984). In heavyweight project organizations (Wheelwright and Clark, 1992), the project manager becomes an entrepreneur (Burgelman and Sayles, 1986). Having unrestricted access to critical resources and to top management, he is also fully responsible for the success or failure of the project, including the creation of new knowledge (as in research) as well as of new products or production techniques (mostly development). His role becomes that of an integrated innovation facilitator: Research, development, production ramp-up but also the design of all related business structures and processes. The core competencies of the company not only consist of technology-bundles but also encompass service-related fields such as logistics and distribution (Prahalad and Hamel, 1990). Similar 
efforts of cross-disciplinary integration are also expected from other R\&D ranks and increasingly from most scientists and engineers.

We observed three general trends concerning the allocation of resources in high-risk or high-profile innovation projects:

1. The riskier the project, the tighter corporate control and the more corporate money was allocated. Risky means not only from the technical or market perspective, but also from the point of view of internal acceptance. If the new technology or project was competence-destroying, acceptance within the company was low (see e.g., Tushman and Rosenkopf, 1992).

2. High R\&D expenses could only be recovered in global markets. But many products required additional localization, which had to be carried out by insiders: Either employees from the regions or, even better, in R\&D units in the region itself. The higher the localization, the more money was allocated to regional $R \& D$. This was one of the main reasons for the expansion of overseas R\&D locations in the early 1990s.

3. The more risk-averse the company, the longer small but risky projects were pursued over the years. Risk was spread out over a large number of small projects and managed with an insurer's attitude: The "law of great numbers" prevented disaster in case an individual project would fail.

\subsection{Close to centers of technology creation and application knowledge}

In most industries, local presence in a cluster of innovation or center of technical excellence is almost mandatory. But R\&D organizations are often organically grown structures (e.g., Hakanson and Zander, 1988; De Meyer and Mizushima, 1989; Krubasik and Schrader, 1990; von Boehmer, et al., 1992; Beckmann and Fischer, 1994). Indeed, the 1990s have been characterized as the decade of jungle growth in R\&D internationalization, when companies vigorously pursued opportunistic development (Gassmann and von Zedtwitz, 1999). At the macroscopic level, the following geographic regions are dominant as the main locus of R\&D activity:

1. Western Europe (particularly Germany and the UK)

2. USA (with a focus on the North-East and the West coast)

3. Japan (agglomeration around Tokyo and Osaka)

4. Southeast Asia (in particular the "tiger" countries, as well as India and China).

In a study of 1021 R\&D sites, Zedtwitz and Gassmann (2002a) found that $73.2 \%$ of all research and $53.4 \%$ of all development sites were located in these regions. Strong attractors were-and continue to be-market reasons and access to local scientific networks, but as illustrated by the responses from our 18 benchmark companies (Table 2), R\&D efficiency and factors not directly related to $R \& D$ (e.g., $M \& A$ ) also drove $R \& D$ internationalization. In some cases, global R\&D managers have to cope with the consequences of location decisions made disrespective of anticipated $R \& D$ performance.

Table 2. What are the most important drivers of globalization?

\begin{tabular}{|c|c|}
\hline Company & Drivers for globalization \\
\hline $\begin{array}{l}\text { Pharma- } \\
\text { ceuticals, } \\
\text { Chemicals, } \\
\text { and Food }\end{array}$ & $\begin{array}{l}\text { Talent: Limitations in quality and supply of technical talent in home country } \\
\text { (DuPont); Different expertise available abroad (Ciba); Localize } \\
\text { management resources (Kao); Sourcing worldwide leading scientists } \\
\text { (Nestlé) }\end{array}$ \\
\hline & $\begin{array}{l}\text { Customers: Different customer requirements (DuPont, Nestlé); Meet local } \\
\text { market requirements (Kao); Supply new technology to manufacturing } \\
\text { facilities abroad (DuPont); Clinical trials are carried out in various } \\
\text { countries (Roche) }\end{array}$ \\
\hline
\end{tabular}


(DuPont); Availability of scientific and market information through information technology (Schering); Complexity of emerging technologies (Ciba); Breakthrough technology (Kao)

Costs: Pay-back of R\&D costs by simultaneous launching (Roche); Global project launches (Schering); Less redundancy due to global coordination (Roche); Costs of doing R\&D, especially contract R\&D (Ciba); Geographic proximity to manufacturing plants reduces the ,scaling-up problem“ (Nestlé)

Regulations: Harmonization of global regulatory environment (Schering); Compliance with local regulatory system (Ciba)

Strategy: Competition for innovation (Schering); Business strategy (Kao) Electronics Customers: Globalization of markets (Xerox, Unisys) and customers (IBM, and Software SAP); Living in the market (HP); Global legal and business processes (SAP); Growth of third world economies (Xerox, Unisys)

Costs \& Communication: Growth of information economies (Xerox); Internet-based global 24-hour communication (Unisys); Low costs of communication (Xerox)

Strategy \& Vision: Corporate philosophy (Canon); Corporate vision (HP)

Talent: Tapping the best R\&D people and mixing their talents (Canon, SAP); Obtain the best intellectual capital (HP); Regional centers of excellence (IBM); Emerging supplier and work forces in developing countries (Unisys)

Universities: Proximity to universities (HP); Contact to leading universities and research institutes (IBM).

Electrical

Customers: Customer orientation (Schindler); Re-use of technologies to satisfy local needs (ABB); Supporting local development (Daimler);

and MaMarket-driven needs (Leica); International partners help to open international markets (MTU); Customer proximity (Leica)

Technology Sourcing: Monitoring technology trends (Daimler); Sourcing know-how in centers of technological excellence (Daimler); Complementary skills of strategic partner (MTU, Hitachi); Taking the best ideas and skills (MTU)

Risk \& Costs: Risk-sharing in large-scale projects (MTU); Economies of scale and scope (MTU)

Regulations: Country-specific regulations and standards (Schindler)

Strategy: Developing the global company (Daimler); Corporate support and drive (Leica); Globalization of business (ABB, Hitachi, MTU); Acquisition of local companies (Schindler)

Enabling Technologies: Information technologies (ABB, Schindler)

\subsection{Integration of $R \& D$ units into global networks}

While corporate organizational evolution increasingly incorporates global stimuli and local responsiveness, companies also build internal complexity and flexibility in order to cope with the specific challenges imposed by technological evolution, industry structure and economic trends. The R\&D structures of many multinational companies have evolved historically through mergers and acquisitions (e.g., Ronstadt, 1978; Pausenberger and Volkmann, 1981; Hakanson and Nobel, 1993), while others started R\&D in the home base and expanded from that ethnocentric and more or less homogeneous R\&D center (Perlmutter, 1969). As a consequence $R \& D$ organizations differ in the degree of cooperation between individual $R \& D$ sites and the dispersion of their internal competencies and knowledge bases (e.g., Ronstadt, 1977; Chiesa, 1996; Kuemmerle, 1997).

Starting up local labs and connecting dispersed R\&D efficiently in aligned distributed innovation processes is far from trivial. Only few companies like IBM, ABB or Novartis have become truly international through building up an integrated $R \& D$ network that is being 
managed as a whole. Political battles must be won, both in the host countries and internally in local country organizations and business units. The not-invented-here syndrome (Katz and Allen, 1982) describes reasons for inefficient exchange of information and knowledge between R\&D units. Better means of communication (through, e.g., modern ICT and travel) only improve international innovation if these socio-political and organizational impediments can be overcome.

\subsection{Establishing overlaying structures}

Effective innovation is based on effective knowledge and technology transfer. In international $\mathrm{R} \& \mathrm{D}$, communication is constrained by geographical distance and organizational dispersion (e.g., Allen, 1977), as well as functional and hierarchical structures (e.g., Burns and Stalker, 1961). Overlaying structures (Gassmann and von Zedtwitz, 1998; von Zedtwitz, 2003a) may overcome some of these impediments:

- A transnational process and project structure that provides basic functional and object integration (e.g., Henderson, 1994; Gassmann, 1997).

- A network structure that provides a framework for informal communication as well as the relationship networks so useful for vertical integration (e.g., Takeuchi and Nonaka, 1986; Brown and Duguid, 1991).

Since the bottom two layers (regional/legal and functional/hierarchical) also impose a sense of order and functionality on R\&D work, they are ultimately detrimental to creativity in R\&D. While many companies still struggle with implementing a situation-driven approach to project management, managing informal networks across corporate boundaries and geographic borders is a remote goal. Most companies pursue at least a mixed centralized/decentralized approach, including, for instance, technology gatekeepers, job-rotation through $R \& D$, business units and external research institutes, project manager pools and professional clubs. However, managing the two upper overlying structures (process and network) requires skills most R\&D managers do not yet possess.

\subsection{Decentralized $R \& D$ processes and virtual innovation teams}

Companies are becoming increasingly dependent on external sources of innovation. R\&D managers try to incorporate outside experts and lead customers into the often rigid framework of internal R\&D processes (O'Hara-Devereaux and Johansen, 1994; Handy, 1995; Chesbrough an Teece, 1996; Harris, et al., 1996; Upton and McAfee, 1996). Supported by modern information and communication technology (ICT) „virtual project teams“ are formed that are spread out over several locations and organizational boundaries. Four fundamental factors determine the degree of decentralization of $R \& D$ projects:

- Type of innovation: incremental vs. radical (Utterback, 1994; Christensen, 1997)

- Systemic nature of the project: systemic vs. autonomous (Chesbrough and Teece, 1996)

- Mode of knowledge: explicit vs. tacit (Nonaka and Takeuchi, 1995)

- Degree of resource bundling: complementary vs. redundant (McCulloch, 1965; Galbraith, 1973).

Most companies rely on ICT and travel of key project members to facilitate communication and coordination, but besides being expensive, this approach also neglects tacit knowledge and complex forms of interaction - typical forms of communication at the core of innovation.

\subsection{Market and customer-orientation in R\&D}

Organization by product or project focuses the energies of an organization on the customer (Henderson, 1994: 105). A major obstacle to customer orientation is the often dominant technology-push thinking. Internationalized R\&D activities impede efficient communication between R\&D and customers (von Zedtwitz and Gassmann, 2002b). Local variations of taste, 
infrastructure, economic wealth, etc. make it necessary for the innovator to align new products with the often unknown expectations of new customers. Regional operations often compete for scarce centrally allocated $\mathrm{R} \& \mathrm{D}$ budgets or, in the case of business unit financing, fight over who has to pay the bill for the project. Too often managers lose sight of the actual problem to be solved, i.e. the customer value proposition to be offered. Despite much public acclaim and many corporate reorganization programs, fulfilling the customers' requests may not solve those problems long-term.

\subsection{Managing interfaces in $R \& D$}

Research is typically concerned with interesting scientific phenomena and fundamental technology breakthroughs, whereas development must satisfy the demands of business units and impatient customers. How harmful is the mismatch between these two worlds? On the one hand, research collocated with development often corrupts and diminishes long-term R\&D. On the other hand, business units sponsoring research may not be able to fund and support the necessary breakthroughs (see e.g., Hirano and Nishigata, 1990; Medcof, 1997).

We identified the following separators between international research and development:

- Geographical distance: Central research labs and decentralized business unit development.

- Differences in reporting structure: Central research versus operating business units;

- Controlling: Strategic research planning with loose control versus milestone planning with sophisticated controlling and performance measurement;

- Time horizons: Long-term knowledge creation versus short-term knowledge transformation in products;

- Knowledge background: Scientists (knowledge experts) versus engineers (knowledge integrators);

- Cultural gap: Blue-sky researchers versus tightly lead-product development with cost and time pressures.

Given the increasing mobility of the knowledge worker of the $21^{\text {st }}$ century, the struggle between free-wheeling scientists and tightly controlled product development engineers should be a thing of the past, but plenty of examples illustrated that the barriers continue to exist between research and development (e.g., Leifer and Triscari, 1987).

\subsection{Processes in transnational $R \& D$}

$\mathrm{R} \& \mathrm{D}$ processes already pose unique problems for project managers (see e.g. Van de Ven et al., 1989; Cooper, 1990; O’Connor, 1994). Most companies engage not only in product development but also in some form of technology research (at least in minimal technology intelligence). Global R\&D processes are even more difficult to manage, when invention, testing, development, production and markets are dispersed worldwide.

There has always been a temptation to introduce regularities and standards (which have contributed so much to the progress of manufacturing) into R\&D. But R\&D is less predictable and less easy to generalize: Research is fundamentally different from development, and pharmaceutical R\&D (for instance) is governed by principles very different from those found in software development. Individual phases of $R \& D$ phases differ greatly in terms of problem-solution approaches, freedom of thought and action, management and control, individual versus group responsibilities, etc. Transnational managers are expected to combine different management styles in one role, while coping with the hassles of international travel and reduced communication quality at the same time.

All these considerations fundamentally affect the nature of a global R\&D organization, but exceed the responsibility of an individual R\&D manager. Top management is expected to define the framework for global innovation processes and commit to it. All to 
often, however, strategic objectives change at the top level (if they ever existed), or are in mismatch with local competencies and expectations.

\subsection{Information and communication technology (ICT) as an enabler of dispersed R\&D}

Without modern information and communication technologies, there would be no transnational R\&D projects. In the 1990 s, the efficiency of transnational R\&D processes has been greatly increased by the use of e-mail, shared databases and remote login (Howells, 1995). But ICT cannot substitute for traditional project management. The lack of personal contact cannot be compensated for by even the most skillful project-leadership-based ICT. Bridging cultural differences becomes much more difficult without face-to-face communication, particularly during the early stages of a project when building team spirit and trust in the project leader and defining a system architecture is so important.

The use of ICT becomes much more difficult when the project requires pooling of complementary resources, which necessitates a high degree of interdisciplinary collaboration and sharing of tacit knowledge. Although experienced R\&D project teams can replace some face-to-face communication with ICT-based communication, De Meyer (1991) showed that regular meetings are important to rebuild trust and confidence. Global knowledge creation cannot function without ICT. The technology itself cannot cope sufficiently with the challenges of bridging geographic distances or time differences, and cannot cope at all with cultural differences.

\subsection{Managing knowledge and human resources}

Ideas - created by individuals - are at the core of every innovation. In multinational companies, R\&D managers supervise highly creative people from diverse cultural and ethnic backgrounds. The internationalization of companies is accompanied by a formalization of processes and structures, which are in juxtaposition to the requirements of creativity and experimentation. There is often no room for creative freedom in efficiency-focused international companies. Additionally, the continuous globalization of technological information requires more attention to knowledge flows. "Knowledge travels (best) with heads," as the adage goes, but travel is expensive and time-consuming. Scientists and engineers are often unwilling to leave family and lifestyle behind to assume assignments abroad. Researchers typically have greater loyalty to their science than their current employer. While capital and goods may be relatively easy to transfer to new locations, people are not. Senior R\&D managers must include this constraint when making strategic R\&D decisions such as the establishment or relocation of R\&D laboratories.

\section{Six Dilemmas in Global R\&D}

Summarizing our analysis of the key challenges of global innovation we noted that:

- Global R\&D problems are not well structured.

- There are no unique solutions for the challenges of global innovation.

Management, however, is forced to make a choice. Too many trade-offs between costs, speed and quality, together with our bounded rationality, lead to dilemmas, i.e. situations in which the decision maker has the choice between two contradictory but equally appropriate alternatives. For instance, given a particular competitive environment, is it better to concentrate $R \& D$ in one location to improve efficiency, or is it better to decentralize to be closer to customers? If the industry or competitive structures change, can we change our R\&D organization as well ... should we change it at all?

Many managers choose the Golden Mean, thereby losing the creative tension so vital for R\&D (Pascale, 1990). The 18 case studies we have gathered show many creative tradeoffs. In our interviews we met with R\&D managers still looking for the single best solution, 
similar to one that Taylor (1913) put forward in manufacturing. Western engineers tend to favor one-to-one relations and unique solutions; they do not like "Yin-and-Yang" situations, i.e. the coexistence of seemingly contradictory patterns. Although we collected many suggestions for overcoming these dilemmas, we feel it is important to manage rather than to eliminate them. First of all, it would not be possible to eliminate these dilemmas because they are inherent to global innovation. Second, it would be detrimental for the strategic flexibility of a company as a whole if creative tension-considered by many as the engine of technological and corporate renewal-was crudely eradicated. Based on our research, we found six principal dilemmas of global innovation:

1. Local versus global

2. Processes versus hierarchy

3. Creativity versus discipline

4. Control versus open source

5. Face-to-face versus ICT

6. Long-term versus short-term

\subsection{Local versus global}

Strategic decisions have to be made under local-versus-global considerations (e.g., Bartlett and Ghoshal, 1989; Asakawa, 1996 for R\&D): How much autonomy should be granted to a local R\&D unit? Too much freedom leads to reinventing the wheel. Not many companies can afford this sort of luxury in times of scarce R\&D budgets and escalating development costs. Overly tight control could hinder creativity and optimal exploitation of local competencies.

Global sourcing is not limited only to purchasing departments. Due to the widespread use of the Internet, information no longer has geographic limitations. Even very small companies can afford to source knowledge on a global scale. However, information obtained via ICT is mainly restricted to relatively structured data, i.e. explicit knowledge. Research experience and know-how cannot be accumulated by downloading publications from the Internet. The global village has its limits when it comes to the diffusion of tacit knowledge and trust.

On the market side the same principle applies: "Our market is different" is the most often heard argument to support local autonomy. How much does a product need to be adapted for regional market requirements? Customization and tailored products for every specific market segment or even customer may increase revenues but also increase costs: Developing new, slightly different product for each request can easily incur hidden variant costs. Therefore, many companies have standardized hidden key components and only adapt visible parts to regional markets. But there is no single solution to the goal conflict between local effectiveness and global efficiency.

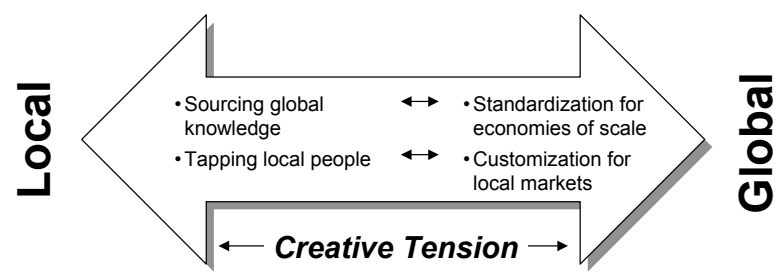

Fig. 2. Local effectiveness versus global efficiency.

\section{ABB GT 24/26 and IBM-VSE: Comparison of Two International Innovation Projects}

In the early 1990s, ABB decided to re-enter the high-power gas turbine market. Time-tomarket was considered more important than cost-effectiveness, as late market-entry was associated with high opportunity costs. $\mathrm{ABB}$ established a project team near its corporate R\&D center in Baden, Switzerland, composed of several hundred engineers and scientists 
from twenty nations. This heavyweight $R \& D$ center was responsible for the lion's share of the R\&D work. However, several ABB R\&D units cooperated in this project, such as ABB Moscow in engineering and ABB Mannheim with specific development tasks. MTU Munich contributed key mechanical elements. Jersey Central Power \& Light in the US acted as a lead user and built and tested the first prototype. Project coordination resided in Baden, Switzerland.

IBM pursued a different approach with its VSE (Virtual Storage Extended) development. Eleven R\&D units participated in this project, including core component developers in R\&D units in Stuttgart (Germany), Hursley (UK), Santa Theresa and New York (USA). More than 150 engineers were involved worldwide. The project office was established in Stuttgart, coordinating technical and managerial responsibilities. However, Stuttgart did not exert directive authority over these units: most of the project was self-coordinated and required active cooperation of several R\&D units. Subsequent releases and repeated projects established sophisticated conflict resolution and decentralized project management schemes.

\subsection{Processes versus hierarchy}

First-generation international $\mathrm{R} \& \mathrm{D}$ organizations are characterized by $\mathrm{R} \& \mathrm{D}$ duplication. More advanced R\&D organizations assign technical and product competencies to individual $R \& D$ units. This permits the concentration of resources to reach critical size and economies of scale. At the same time, however, this leads to transnational innovation processes, as R\&D units from several locations must pool their resources and align their efforts to develop new products or technology.

Interdisciplinary cooperation within projects increases. Process-oriented teams must be able to overcome boundaries of location and specialization, and yet keep their focus on their own special competence. These teams form overlaying organizational structures that ensure a company's long-term innovative capability. At the same time, these teams create conflicts with classical line organization structures. Open communication and common values (vision/mission) can help reduce these conflicts, which are so difficult to manage on a global scale.

Process structures and information technologies that reach beyond national boundaries are essential prerequisites. However, tailor-made processes and extensive use of state-of-the-art communication technologies do not lead to the desired project success if the human factor is neglected. Particularly in more complex global environments, innovation cannot be seen as a linear process (e.g., Van de Ven et al., 1989). R\&D processes cannot be managed and measured like repetitive routine processes in production. Deterministic models of managing innovation processes have given way to models incorporating chaos theory and randomness. It must be possible to restrict chaos to the early stages of innovation: Chaos and people management must lead to innovative new concepts and well-suited processes, while adhering to discipline yields the efficiency needed in the later stages.

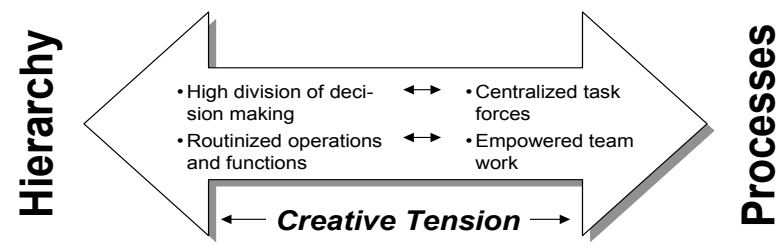

Fig. 3. Hierarchy versus processes.

\section{Carilon: Overcoming Organizational and Geographical Boundaries at Shell}

An example of a company with highly competent but dispersed R\&D network is Royal Dutch/Shell. In 1998, Shell spent almost US\$ 700 million on R\&D carried out by 15 research establishments all over the world. Shell's early experience with coordinating distributed R\&D efforts is illustrated in the case of Carilon, a multiple-application polymer developed between 
1984 and 1997. This polymer was first developed in a Belgian R\&D laboratory, but then the central laboratory in Amsterdam got involved and - as it was decided that the United States was going to be the ideal target market - the Westhollow Research Center in Houston, Texas. For some time there was duplicate R\&D activity and the presence of the Not-Invented-Here syndrome among researchers in various participating sites. With the prospective polymer development not making significant progress, Shell eventually overcame some of the wellestablished 'laws' cherished in conventional $\mathrm{R} \& \mathrm{D}$, and as a consequence gave one R\&D center complete responsibility for the polymer's development. The additionally enforced focus on market development turned Carilon into a success story. What was initially known as "the most poorly managed project in the company's history" (quote of a Shell manager) became its first successful multinational product development.

\subsection{Creativity versus discipline}

Many large companies spend more on creating new knowledge than they spend on investments (Kodama, 1995: 20). R\&D globalization often aggravates the problem of increasing $R \& D$ complexity and product variety. Most $R \& D$ departments therefore support planning by an almost unbelievable number of formal control mechanisms. Small dynamic companies control R\&D by their annual R\&D budget alone.

With time, the innovation process progresses from a highly creative phase to a more structured and disciplined one. As innovation is a cross-functional process, members of R\&D, manufacturing, marketing and sales contribute new ideas and impose new requirements at different stages along the way. However, traditional planning methods based solely on complexity reduction, work breakdown structures and task simplification are no longer appropriate in a dynamic and interdisciplinary project environment. Based on product liability and misinterpreted ISO documentation requirements, managers repeatedly attempt to translate the reliability and controllability imposed on routine processes (as in manufacturing) into innovation processes. The results often do not match their expectations. Because R\&D operates under constant time pressure, tight control and regulation lead to deadlocks that result in uncontrollable "gray zones" and further lengthen development cycle times.

Not every company needs the same degree of integration and process orientation. R\&D always has to balance discipline and creativity, standardization and variety, organizational slack and cost cutting. The more project management focuses on planning and standardization, the greater the efficiency and the shorter the cycle time, but the less freedom there is for creative chaos. Stronger integration of project management according to objects, functions and hierarchies will increase management complexity, but at the same time improve R\&D effectiveness and efficiency. The stage-gate concept (e.g., Cooper and Kleinschmidt, 1991) considers these contradictions and attempts to integrate project management according to the three factors of market, specialization and technologies. These factors determine the choice of project management methods to be used.

During the second half of the 1990s, new business creation and incubation units posed new challenges to established R\&D departments. R\&D came under pressure to bridge between creativity and discipline more effectively. Internal ventures and start-ups appear were less restricted than $R \& D$ projects, and therefore approached this fundamental tension with more flexibility. We expect that R\&D will, in the future, be more incubation than science centered.

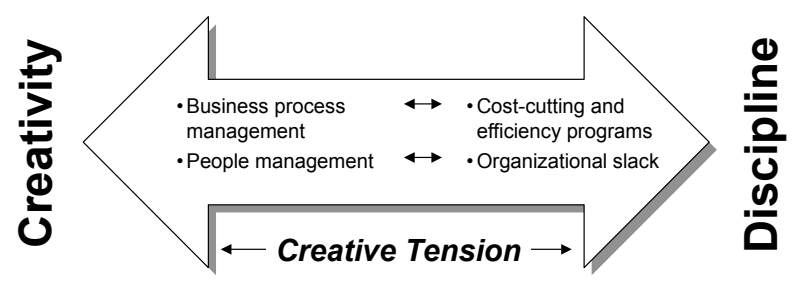

Fig. 4. Creativity versus discipline. 


\section{Xerox and Canon: Evolutions of Research and Development}

Often disparagingly regarded as an 'Ivory tower,' corporate research laboratories may develop strong development skills. Burgelman and Sayles (1986: 19) quote the case of Xerox's Palo Alto Research laboratory which was not supposed to do new product development but nevertheless came up with a great product eventually: ALTO, a unique personal computer widely used and liked within the company. But since an alternative design named STAR was under development elsewhere in Xerox, ALTO was not further supported. In general, however, allowing for product development capabilities in research reduces the emergence of highly sophisticated yet useless products and hence improves the likelihood of successful technology and knowledge transfer to downstream functions. For instance, Xerox Research in Grenoble, France, spun out a development team that established a new Xerox product development unit near the research site. Another example is Criterion Software, which is based on a 3-D software technology developed at Canon's UK research lab. The original inventor became head of technical development while one of his former Canon colleagues, a man with strong business orientation, assumed management responsibilities. Criterion quickly grew to more than fifty employees, many of them hired externally, although Canon retained a financial stake in the company and strong joint development linkages. Corporate incubators try to systematically support and exploit these effects. Both cases illustrate the interplay of organizational flexibility and innovation, as well as the changing perspectives of creativity and discipline.

\subsection{Control versus open source}

R\&D labs have limited capacities. R\&D depth was reduced in the 1990 s, as manufacturing depth was reduced in the 1980s. R\&D labs are productive when they are selective, when they do what they have already done many times and when they focus on core capabilities. The organizational emphasis is shifting from self-made to bought-in: suppliers, independent laboratories, IP intermediaries and universities are typical sources.

Under the technological core capability paradigm the new operating tenet is to "own only what you must; influence all you can" (Harris et al., 1996). The most successful virtual companies are at the center of networks that are far from egalitarian (Chesbrough and Teece, 1996: 70). They retain control over the network of their partners. This position cannot be maintained unless the company directly controls some key technologies. Companies need a process to discriminate between "must have" (technologies that must be owned) and "nice to have" technologies.

However, many R\&D organizations still fear to lose ownership over what they consider future key technologies. Most companies apply portfolios to manage their outsourcing decisions; they provide standard strategies for well-defined situations. Many use technology life cycles to make R\&D investment, control and divestiture recommendations. But the decision to give up existing technologies is one of the most difficult management decisions (e.g., Grove, 1997).

Equally difficult is the decision to engage in open source innovation. Without being able to control many of the elements that are necessary to succeed in networked innovation, companies shy away from investing resources and time. A permanent danger is the loss of proprietary intellectual property through leakages and open communication in such networks. Worse, sometimes, are the prospects of sponsoring innovations that the company can eventually not exploit oneself because someone else in the network (perhaps a competitor) has assumed control. While it becomes increasingly clear that a single company cannot develop all the technologies it requires in competition, senior R\&D directors realize that the management of international standards, open source networks and dominant designs must be added to their repertoire. 


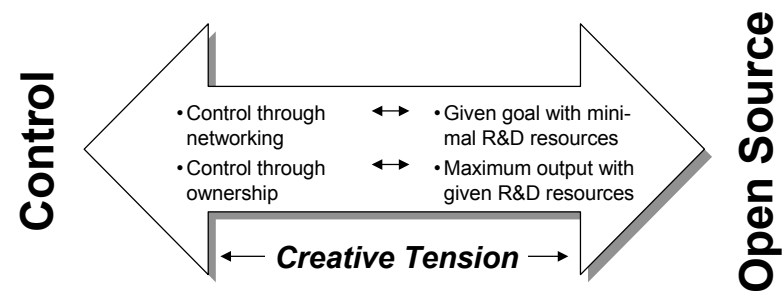

Fig. 5. Control versus open source.

\section{Roche: Outsourcing and Virtual R\&D}

Roche outsourced much of the R\&D process to specialized partners and suppliers, or set-up focused external R\&D service providers. For instance, Roche established Protodigm, a "virtual drug development company" in London, UK (Hofmann, 1997). In one typical case, Protodigm learned of a certain molecule, i.e. a prospective new medical substance, being discovered in a university laboratory. Protodigm then facilitated further research by guiding the R\&D process: It contacted specialized companies for testing the substance, coordinated the first clinical trials, and contracted out production, second-stage clinical development, manufacturability tests, drug registration, marketing, and even sales. In 1997, ten Protodigm employees simultaneously oversaw three drugs development projects in various stages of pharmaceutical development. Protodigm selected the most qualified subcontractor for each stage of $R \& D$, thus reducing overall $R \& D$ costs and development time. The objective were cutting down R\&D costs by $40 \%$ without jeopardizing the already tight development schedule. Merck was said to have saved US\$ 170 million with this type of outsourcing in 1996. Behind this trend was a fundamental change in the pharmaceutical industry: Basic research was increasingly sourced out to big universities or small specialized companies.

\subsection{Face to face versus ICT}

The information revolution is transforming the nature of competition (Porter, 1985). According to Davis and Botkin (1994: 170) the worldwide amount of knowledge doubles every seven years. For instance, the number of scientific journals was 100 at the beginning of the 19th century, 1,000 around 1850 , over 10,000 around 1900 and about 100,000 journals around 2000. Over 6,000 scientific publications are released daily these days. Every 10 to 15 years the amount of published scientific literature doubles. These numbers have a human equivalent: Over 5 million people work in the area of knowledge production in R\&D departments: This is approximately $90 \%$ of all scientists who have ever lived (Nefiodow, 1990).

$R \& D$ is the most important element in industrial technology intensive organizations to source, filter, generate and diffuse knowledge. „Science does not advance by piling up information - it organizes information and compresses it" (Simon, 1997: 226). ICT is almost a "must" in R\&D organizations. Access to e-mail, video- and teleconferencing, and groupware is possible almost everywhere. The rapid increase of performance compared to costs leads to the paradoxical phenomenon that some R\&D sites in developing countries leapfrog technological generations and install more advanced infrastructure than the R\&D headquarter.

Although ICT is a necessary tool for global knowledge management, it is not yet a sufficient one. ICT can support the exchange of explicit knowledge, but learning between individuals requires a basis of trust not easily facilitated by ICT (De Meyer, 1991). Engineers and scientists must be allowed sufficient freedom to build up a network of informal contacts for sharing such knowledge (Allen, 1977; Katz and Tushman, 1981). Managers realize that 
the procedural and tacit know-how of the project team members is at least as important as the documented and explicit knowledge. But tacit knowledge is almost exclusively shared face to face.

Even face-to-face contact does not ensure perfect communication. Language problems and different cultural frameworks make communication less straightforward. Communication must be maintained at a regular frequency, as otherwise the trust level between two partners is too low to allow meaningful communication. Face-to-face communication does not need to be exclusively verbal-it may include drawing and demonstration. Some of the latest ICT tries to convey haptic and sensory information as well. No satisfactory means of effective tacit long-distance communication is in sight. Additionally, the amount of explicitly transferable knowledge has tremendously increased: The challenge will not only be to manage face-to-face communication, but also how to manage and make sense of millions of documents and other pieces of information collected in projects, on the Internet, or from specialized information service providers.

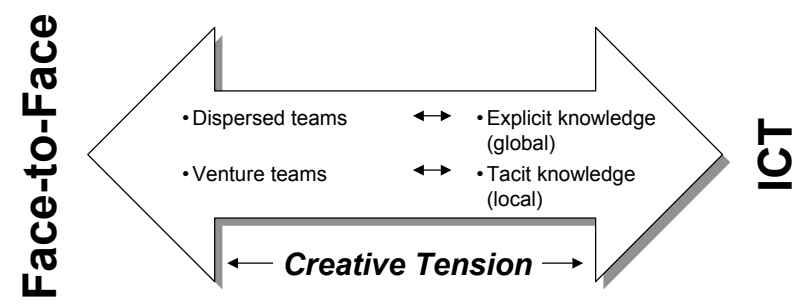

Fig. 6. Face-to-face contact versus use of modern ICT.

\section{IBM and Roche: Knowledge Travels with Heads}

IBM uses both face-to-face and ICT tools in international R\&D projects, but applies different weights in subsequent phases of the project. In the early phases of planning and design IBM relies on face-to-face meetings and conferences. Once a common understanding has been established, video conferences are used. For later stages of coordination (when only detail adaptations are required), IBM promotes e-mail and telephone communication. E-mail is preferred over the telephone as it is cheaper and culturally less sensitive. For instance, IBM made the experience that Germans dislike talking to answering machines and avoid using voice mail systems. Also, e-mail transcripts are more readily quoted and usable in project documentation. For the final meetings, such as roll-out coordination, project hand-overs and post-project reviews, personal face-to-face meetings are again preferred.

R\&D communication essentially fosters learning opportunities. Hoffmann-La Roche uses an international project management team to facilitate learning transfer between projects and deliberately does not integrate associated project managers in its organizational hierarchy in order to optimize knowledge transfer between projects. Every project manager is fully assigned to this geographically decentralized department. The director of this virtual resource pool assigns his people as managers to projects also as part of a global program to ensure standards in quality and project procedures. Upon completion of a project, the project manager returns to the resource pool and awaits his next assignment. Roche thus manages to retain much of the valuable procedural know-how to conduct and lead international projects not only inside the company, but also in a position where it can be reapplied when needed.

\subsection{Long-term versus short-term}

There has always been a gap between long-term and short-term pressures in R\&D. Critical in successful innovation is the timing of the new product or service to be introduced in a market. Early or late introduction is equally detrimental (e.g., Foster, 1986). Products offered too late usually face stiff competition from similar products, and customers may have adopted a competing design or product architecture. Profit margins for late products are thus significantly lower (e.g., me-too drugs in the pharmaceutical industry). Products offered too 
early may fail because customers do not yet experience the need for them, and these products cannot benefit from complementary offerings (e.g., Beta-Max vs. VHS, Rosenbloom and Cusumano, 1987). Companies therefore often invest in educating the market about the benefits of its product (additional investments in advertising and marketing) to convince the potential customer of the anticipated long-term benefits of the new product (e.g., failure of the Apple Lisa, or the Apple Newton). Introducing the right product at the right time (rather than just as quickly as possible) is critical in innovation.

The danger of missing this window of opportunity is great, as numerous examples of new product introduction failures document. There are two principal approaches how innovating companies attempt to cope with this problem:

1) Researching future customer benefits and assessing emerging technology potentials: Using various forecasting and monitoring techniques, companies predict changes in both the technology pull as well as the technology demand side, and derive strategic implications how long-term innovation efforts in their R\&D organizations can meet these expected customer benefits. The goal is to see farther and more clearly what is ahead.

2) Speeding up new product development and decreasing time-to-market: Customers identify suppliers that can deliver the best solutions to their current needs nearly realtime. Long innovation times are a competitive disadvantage, especially in industries with rapidly changing requirements and thus moving targets. Companies therefore try to reduce $R \& D$ cycle times and speed up the innovation process. Ideally, R\&D would be an instantaneous process; practically, one has to beat competition by a time frame that is equal or exceeds in value over the costs of identifying, negotiating and switching to a new supplier. The goal is to be as fast as possible.

However, these two strategic paradigms of innovation have led to a disintegration of the overall R\&D effort. As a consequence, R\&D departments have been compartmentalized and functionally isolated. Communications between of research and development units and the alignment of overarching innovation objectives have suffered. At a global level, research is building capacity abroad to source and absorb scientific and long-term technology information. Development, on the other hand, is following market potentials and localizes new products to customer needs. This adds a global dimension to the problem of disintegrated innovation.

Moreover, the gap between these two critical R\&D capabilities is widening. While new product development has to deliver in shorter and shorter time frames, sustainable innovation is increasingly based on integrated technology planning and the phased introduction of compatible modules and systems that extend the usefulness as well as economic and environmental sustainability of products. This is a fundamental dilemma that some companies have tried to address by reintegrating R\&D departments, or by establishing special liaison officers between short and long-term R\&D teams, or by imposing technology roadmaps and scenario planning on R\&D departments. None of these approaches has produced thoroughly satisfactory results so far; the dilemma of diverging short and long-term innovative capabilities continues to persist.

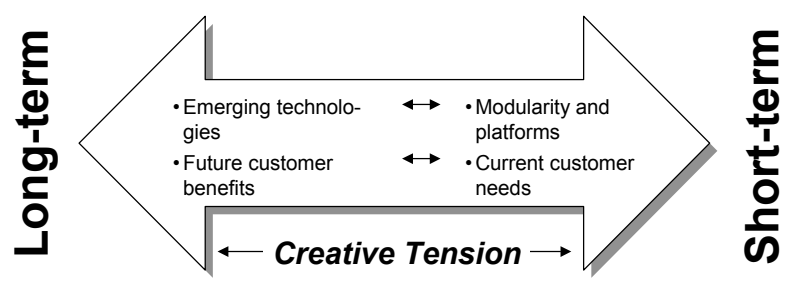

Fig. 7. Long-term technology anticipation versus short-term customer reaction. 


\section{ABB and NEC: Managing Long-Term and Short-Term R\&D}

Technology top-management at ABB was convinced that 'project creation' is one of the biggest challenges in $\mathrm{R} \& \mathrm{D}$. ABB distinguished between $\mathrm{R} \& \mathrm{D}$ for existing products, for next generation products, and for future technologies. Generally, their projects were two-channel funded: At least one business unit had to demonstrate its interest in the R\&D outcome by sharing the project costs with corporate headquarters. This was also an effective means to ensure the receiver's interest in transferring the developed technology successfully.

NEC, Hitachi, Xerox, and 3M, among others, established a three-tier organization distinguishing $R \& D$ work according to time horizon. A three-tier organization is realized in very large companies. R\&D is organized, and separated, according to time horizons and specific competencies.

At NEC, long-term basic and fundamental research was carried out in the R\&D Group. Three development laboratories were concerned with medium-term R\&D, whereas system \& product engineering units performed short-term application engineering. For instance, while the engineering labs were working on the $64 \mathrm{Mbit}$ DRAM, development labs work on the 128/256 Mbit DRAM, and the R\&D Group conducted research that prepared for the 1 Gbit version. With this deliberately introduced separation, technology transfer and communication mechanisms rose in importance. The R\&D Group worked on R\&D for the 'day after tomorrow.' Development centers carried out R\&D for 'tomorrow,' while Engineering Units were concerned with problems of 'today.' This distinction was also reflected in funding schemes and the location of the R\&D work.

\section{Implications and Outlook}

\subsection{Managerial Implications}

What can R\&D managers do to apply the insights of global dilemmas? We want to emphasize three important lessons:

1. International evolution in $R \& D$ is inevitable and should be exploited for organizational prototyping.

2. Transnational $R \& D$ is best separated into two distinctly managed phases of innovation.

3. There are four principal archetypes of international $R \& D$ project organization.

\subsubsection{International evolution of $R \& D$ organization}

The international R\&D organization of a firm is neither rigid nor uniformly understood throughout the company and subject to continuous change. There are five trends that characterize the evolution of organization in international R\&D:

1. Orientation of $R \& D$ processes towards international markets and knowledge centers;

2. Establishment of tightly coordinated technology listening posts;

3. Increase of autonomy and authority of foreign R\&D sites;

4. Tighter integration of decentralized R\&D units;

5. Increased coordination and re-centralization of $R \& D$ activities in fewer leading research centers in order to improve global efficiency.

These trends are fundamentally linked with the flow of information, assignment of competency and transfer of authority in international R\&D organization, and are central for international technology and knowledge transfer between dispersed R\&D sites. Local R\&D sites also undergo internal evolution: technology listening posts may develop into research centers, and technical service units into full-fledged development sites with a worldwide product mandate (see Gassmann and von Zedtwitz, 1999).

Underlying these trends are market and technology pull factors, internal and national politics, efficiency considerations, and many other, sometimes not technology or R\&D relevant rationales. Personal determination and commitment by entrepreneurial R\&D 
directors have given individual $R \& D$ units new missions and new competencies in $R \& D$ networks. Often, duplication of R\&D conducted elsewhere was not the successful route to independence and uniqueness. Initial $\mathrm{R} \& \mathrm{D}$ directors tried (either with or without top management approval) new technologies, new projects, new missions, and new organizational forms with their new R\&D units (see von Zedtwitz, 2003b, for a recent classification). If successful, these approaches were adopted by other R\&D units. Relatively large geographical and power distances were sometimes beneficial to develop new forms of organization. The companies that are doing well in global innovation are those who are able to maintain a healthy rate of evolution and flexibility to adapt more appropriate forms of doing $R \& D$ in remote locations.

\subsubsection{Two phases in transnational innovation processes}

Innovation processes are characterized by a transformation of the focus of work from creativity to discipline. The first phase of creativity aims for ensuring effectiveness of the results, while the second phase of discipline is concerned about making sure that these results are efficiently implemented (see e.g., Gassmann and von Zedtwitz, 2003a).

1) Creative phase: The process in the early $R \& D$ phase is highly non-linear. Good ideas require knowledgeable promotion. Although knowledge sourcing for new technologies is not limited geographically, invention is typically local. The definition of a system architecture is crucial and concludes the pre-project phase.

2) Implementation phase: The development phase has to be carried out rigorously and efficiently. Discipline is dominating over diversity. Creativity may be detrimental to overall innovation and must be redirected. In this phase global teamwork is possible and sometimes necessary, but clear definition of work packages and interfaces is required.

These two phases are then followed by the market introduction of the product. Different strategies are possible at the global level: Entering new markets one by one (waterfall strategy) or coordinating the spread of the product at the same time ('big bang introduction', simultaneous launch).

Companies in the pharmaceutical industry probably provide the best examples of two-phase innovation. For instance, there are clearly defined milestones and board decisions that determine when and how a drug candidate transitions from research to clinical development. Similar considerations can be found in other industries, but should become more explicit in guiding transnational process management.

\subsubsection{Four archetypes of international $R \& D$ projects}

As outline further above, international R\&D projects can be distinguished along four principal determinants. First, the type of innovation can be either incremental or radical. Maintenanceof-line projects are typical incremental; breakthrough projects are radical. Second, the nature of a project can by systemic or autonomous. Systemic projects are characterized by a high degree of interdependence of work tasks and technical components; autonomous projects can afford to work on a highly modular part of a system, such as a better keyboard in a PC environment. Third, projects also differ in terms of the preferred knowledge exchange mode, either explicit or tacit. Forth, project resources may be distributed complementary rather than redundant. In redundant-resource project organizations, similar knowledge and resources are shared in different project locations, improving communication and the speed of integrating modules.

Depending on these factors, global R\&D projects are carried out in: 1) highly decentralized autonomous teams; 2) teams coordinated by a system architect; 3) teams directed by core teams; or 4) centralized venture teams. The centralization of R\&D projects is necessary for radical innovation, systemic project work, prevalence of tacit knowledge and the presence of complementary resources (see Gassmann and von Zedtwitz, 2003b, for an indepth review). The decentralization of R\&D projects is possible for incremental innovation, autonomous project work, prevalence of explicit knowledge and the presence of redundant 
resources. For each of those project types, the role of the project manager changes significantly.

\subsection{Outlook and Trends}

The companies in our study sample demonstrated how they deployed a sophisticated array of technology, innovation, and R\&D strategies. However, not every multinational company has a long-term technology strategy: A benchmark study conducted by one of the author's institute found that just slightly more than half of 39 multinational companies had formally written technology strategies at the corporate level and defined technical core competencies. Small and medium-sized companies, in particular, are very often missing explicit technology strategies.

Technologies are handled reactively: The three most important drivers for innovation are customers, suppliers and employees. As small companies are increasingly targeting global markets, these companies will need simple, efficient concepts that are not yet available. The rather complex, historically grown R\&D patterns of the large multinationals will need simplification that cannot be achieved without better theories on global R\&D.

An area generally ignored by conventional R\&D researchers is services. "Services are simply too heterogeneous to be an interesting category," remarked Thurow (1996: 27). Inroads are being made for instance in electronic commerce and health care. Hospitals are bundles of high-tech yet poorly managed in many regulated economies. The share of manufacturing in a service-oriented society will decrease, but the significance of R\&D will nevertheless grow because of more demanding customers and greater technological potentials.

Global R\&D will thus likely incorporate the following trends: more system orientation, more reductionism, more mobility, more open networking and more harmonization.

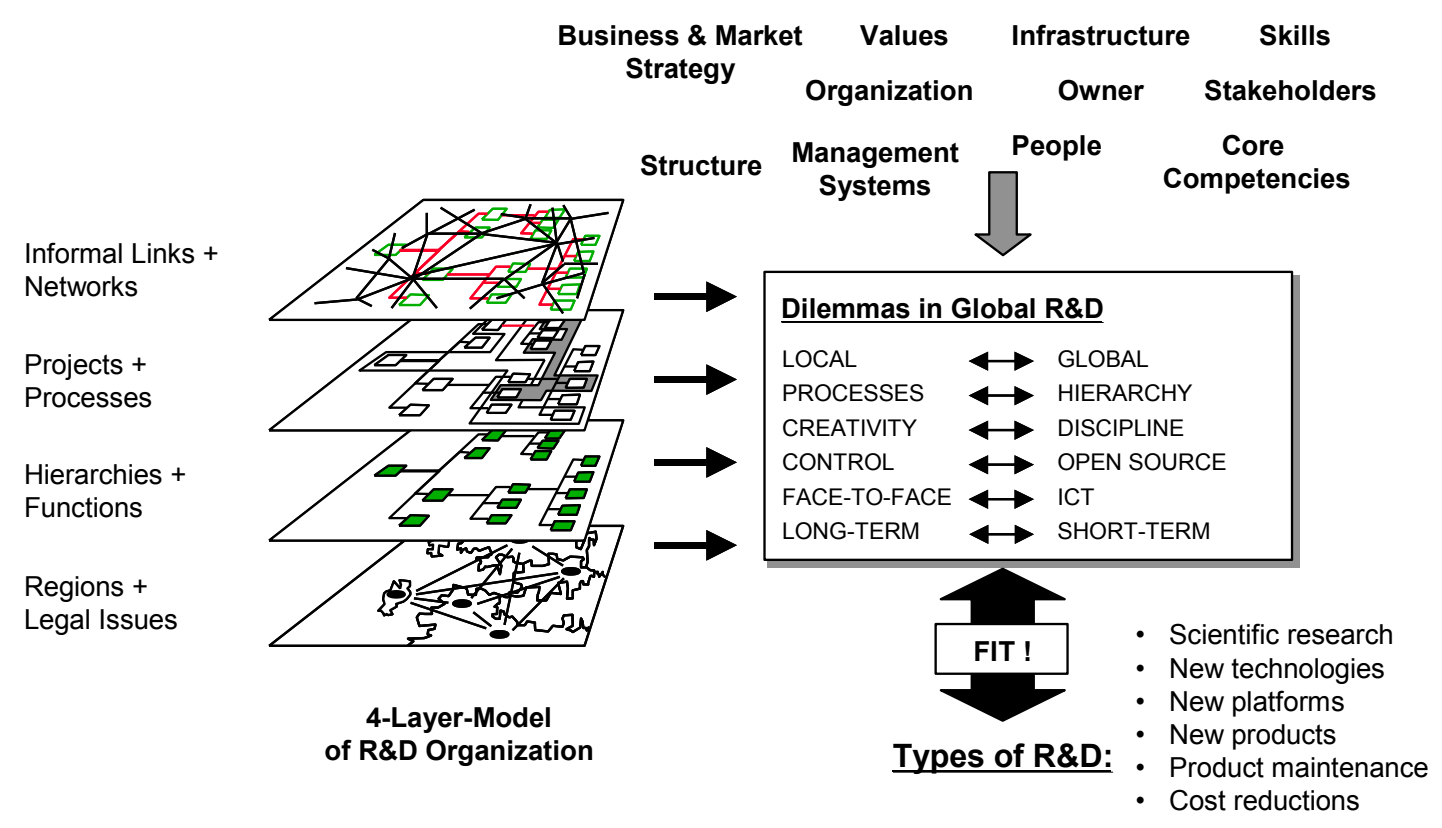

Fig. 8. There is no single best solution - R\&D management has to fit with the targeted R\&D type. 
1. More system orientation: With the conventional borders of modern products vanishing, engineers will have to be able to look beyond their established fields of technological expertise and integrate unexpected functionalities, other uses, different cultures, and sometimes uncomfortable philosophies.

2. More reductionism: Holism is important for systems but hasn't changed engineering. Physical and mathematical models have increased predictive power. Simulation is replacing experimentation, and approximations are replacing exact solutions. For example, pharmaceutical research is being changed by computational chemistry and genomics. Illness is no longer considered to be a sign of too many bacteria, as in Pasteur's time, or a faulty chemical process but rather an information defect in the human genetic code (Drews, 1998: 103).

3. More mobility: Advances in telecommunication have already made decentralized work possible; advances in transportation will further improve communication were ICT still fails. New forms of organizing work will provide more adequate frameworks to deliver innovation. R\&D employees of the future will be more mobile and flexible chose their own most conducive places and time of work.

4. More open networking: Economies of scale in $R \& D$ will not be measured in employees per organization but rather in spheres of influence. Small players who know better how to leverage their core capabilities in a network of suppliers and customers of technology will fare better than the old flagships of corporate R\&D.

5. More harmonization: International technical and cultural norms facilitate the spread of global products. Regionalism is a reaction to international integration supported by television, travel, and the Internet. In science, English is the common language that facilitates communication: the critical success factor in R\&D. Scientists and engineers are trained the same way everywhere in the world: Scientific laws and fundamental engineering principles know no national boundaries.

\section{$7 \quad$ Conclusion}

This paper summarized some of the most frequent challenges in global innovation. We also described six fundamental dilemmas:

- Local versus global

- Process versus hierarchy

- Creativity versus discipline

- Control versus open source

- Face to face versus ICT

- Short-term versus long-term

As R\&D organizations have developed from centralized and geographically confined towards distributed and open structures, these dilemmas have risen in urgency. Dilemmas are not negative per se. To the contrary, in a dilemma both alternative courses of action are equally valuable. The various approaches to managing these dilemmas-including those that attempt to eliminate them altogether-have given rise to an impressive body of know-how among $R \& D$ managers and $R \& D$ scientists. One thing was confirmed by nearly all our interview partners: Looking ten years ahead, regardless of the rapid evolution of modern technologies, new organizational concepts and even more efficient tools, the individual and teams will remain at the core of international management of innovation. 


\section{$8 \quad$ References}

Allen, T.J. (1977): Managing the Flow of Technology - Technology Transfer and the Dissemination of Technological Information within the R\&D Organization. Cambridge, London.

Asakawa, K. (1996): External-Internal Linkages and Overseas Autonomy-Control Tension: The Management Dilemma of the Japanese R\&D in Europe. IEEE Transactions on Engineering Management, 43, 1, 24-32.

Bartlett, C.A.; Ghoshal, S. (1989): Managing Across Borders: The Transnational Solution. Boston: Harvard Business School Press.

Beckmann, C.; Fischer, J. (1994): Einflussfaktoren auf die Internationalisierung von Forschung und Entwicklung in der Chemischen und Pharmazeutischen Industrie. Zeitschrift für Betriebswirtschaftliche Forschung 46, 7/8, 630-657.

Boutellier, R.; Gassmann, O.; Macho, H.; Roux, M. (1998): Management of Dispersed R\&D Teams. $R \& D$ Management, Vol. 28, No. 1, 13-25.

Boutellier, R.; Gassmann, O.; von Zedtwitz, M. (1999): Managing Global Innovation. Berlin, Tokyo, New York: Springer.

Brown, J.-S.; Duguid, P. (1991): Organizational Learning and Communities-of-Practice: Toward a Unified View of Working, Learning, and Innovation. Organization Science, 2, 1, 40-57.

Burgelman, R.; Sayles, L. (1986): Inside Corporate Innovation. New York: The Free Press.

Burns, T.; Stalker, G.M. (1961): The Management of Innovation. Oxford University Press.

Chesbrough, H.W.; Teece, D.J. (1996): When is Virtual Virtuous? Organizing for Innovation, in: Harvard Business Review 74, 1, 65-73.

Chiesa, V. (1996a): Managing the Internationalization of R\&D Activities. IEEE Transactions on Engineering Management, 43, 1, 7-23

Christensen, C. (1997): The Innovator's Dilemma-When New Technologies Cause Great Firms to Fail. Boston: Harvard Business School Press.

Cooper, R. and Kleinschmidt, E. (1991). New Product Processes at Leading Industrial Firms. Industrial Marketing Management 20, 137-147.

Cooper, R.G. (1990): New Products: What Distinguishes the Winners? Research Technology Management 33, 6, 27-31.

Davis, S; Botkin, J. (1994): The Coming of Knowledge-Based Business. Harvard Business Review, 72, 5, 165-170.

De Meyer, A. (1991): Tech Talk: How Managers Are Stimulating Global R\&D Communication. Sloan Management Review 32, 3, 49-58.

De Meyer, A., Mizushima, A. (1989): Global R\&D Management. R\&D Management 19, 2, $135-146$.

Drews, J. (1998): Die verspielte Zukunft. Basel, Birkhäuser.

Foster, R. (1986): Timing Technological Transitions, Reprinted in Tushman, M.; Moore, W. (Editors, 1988): Readings in the Management of Innovation, $2^{\text {nd }}$ ed. HarperBusiness.

Galbraith, J. (1973): Designing Complex Organizations. Reading: Addison-Wesley.

Gassmann, O. (1997). Internationales F\&E-Management. Munich: Oldenbourg.

Gassmann, O.; von Zedtwitz, M. (1998): Organization of Industrial R\&D on a Global Scale, in: R\&D Management, Vol. 28, No. 3, 147-161.

Gassmann, O.; von Zedtwitz, M. (1999): New Concepts and Trends in International R\&D Organization: in Research Policy, Vol. 28, 231-250.

Gassmann, O.; von Zedtwitz, M. (2003a): Innovation Processes in Transnational Corporations. Shavinina, L. (Editor): The International Handbook on Innovation. Pergamon: Oxford, Part IX, Chpt. 4, 702-714.

Gassmann, O.; von Zedtwitz, M. (2003b): Trends and Determinants of Managing Virtual R\&D Teams. R\&D Management, Vol. 33, No. 3, 243-262.

Grove, A.S. (1997): Only the paranoid survive. New York: HarperBusiness. 
Håkanson, L.; Nobel, R. (1993): Determinants of Foreign R\&D in Swedish Multinationals. Research Policy 22, 397-411.

Håkanson, L.; Zander, U. (1988): International Management of R\&D: The Swedish Experience. $R \& D$ Management 18, 3, 217-226.

Handy, C. (1995): The Empty Raincoat-Making Sense of the Future. Arrow Business Books.

Harris, C.; Insinga, R.; Morone, J.; Werle, M. (1996): The Virtual R\&D Lab, in: Research Technology Management 39, 32-36.

Henderson, R. (1994): Managing Innovation in the Information Age. Harvard Business Review, 72, 1, 100-105.

Hirano, Y.; Nishigata, C. (1990): Basic Research in Major Companies of Japan. National Institute of Science and Technology Policy (NISTEP) Report No. 8, Tokyo.

Hofmann, D. (1997): Das virtuelle Unternehmen. NZZ (Oct. 25), 29.

Howells, J. (1995): Going Global: the Use of ICT Networks in Research and Development. Research Policy 24, 169-184.

Katz, R.; Allen, T.J. (1982): Investigating the Not Invented Here (NIH) Syndrome: A Look at the Performance, Tenure, and Communication Patterns of 50 R\&D-Project Groups. $R \& D$ Management 12, 1, 7-19.

Katz, R.; Tushman, M. (1981): An investigation into the managerial roles and career paths of gatekeepers and project supervisors in a major $\mathrm{R} \& \mathrm{D}$ facility. $R \& D$ Management 11, 3, 102-110.

Kodama, F. (1995): Emerging Patterns of Innovation: Sources of Japan's Technological Edge. Boston: Harvard Business School Press.

Krubasik, E.G., Schrader, J. (1990): Globale Forschungs- und Entwicklungsaktivitäten, in: Welge, M.K. (Ed.): Globales Management. Stuttgart, 17-27.

Kuemmerle, W. (1997): Building Effective R\&D Capabilities Abroad. Harvard Business Review, 75, 2, 61-70.

Leifer, R.; Triscari, T. (1987): Research versus Development: Differences and Similarities. IEEE Transactions on Engineering Management, 34, 2, 71-78.

McCulloch, W. (1965): Embodiments of Mind. Cambridge: MIT Press.

Medcof, J.W. (1997): A taxonomy of internationally dispersed technology units and its application to management issues. $R \& D$ Management 27, 4, 301-318.

Nefiodow, L.A. (1990): Der fünfte Kondratieff. Frankfurt.

Nonaka, I.; Takeuchi, H. (1995): The Knowledge-Creating Company. How Japanese Companies Create the Dynamics of Innovation. New York: Oxford.

O'Connor, P. (1994): Implementing a Stage-Gate Process: A Multi-Company Perspective. Journal of Product Innovation Management, 11, 183-200.

O'Hara-Devereaux, M.; Johansen, R. (1994): Globalwork. Bridging Distance, Culture, and Time. San Francisco: Jossey-Bass.

Pascale, R.T. (1990): Managing on the Edge. New York: Touchstone.

Pausenberger, E.; Volkmann, B. (1981): Forschung und Entwicklung in internationalen Unternehmen. $F+E$, 11. Lfg. XI/81, 8400, 1-33.

Perlmutter, H.V. (1969): The Tortuous Evolution of the Multinational Corporation. Columbia Journal of World Business 4, 9-18.

Prahalad, C.K.; Hamel, G. (1990): The core competence of the corporation. Harvard Business Review, 68, 3, 79-91.

Porter, M.E. (1985): Competitive Advantage: Creating and Sustaining Superior Performance. New York: Free Press.

Ronstadt, R.C. (1977): Research and Development Abroad by U.S. Multinationals. New York: Praeger.

Ronstadt, R.C. (1978): International R\&D: The Establishment and Evolution of Research and Development Abroad by Seven U.S. Multinationals. Journal for International Business Studies 9, 7-24.

Rosenbloom, R.; Cusumano, M. (1987): Technological Pioneering and Competitive Advantage: The Birth of the VCR Industry. California Management Review, 29, 4, $51-76$. 
Simon, H.A. (1997): Administrative Behaviour. New York: The Free Press.

Takeuchi, H.; Nonaka, I. (1986): The New New Product Development Game. Harvard Business Review, 64, 1, 137-146.

Taylor, W. (1913): The Principles of Scientific Management. New York: Harper\&Row.

Thurow, L. (1996): The future of capitalism. Penguin. PLACE?

Tushman, M.L.; Rosenkopf, L. (1992): Organizational Determinants of Technological Change: Toward a Sociology of Technological Evolution, in: Burgelman, R.A.; Maidique, M. Wheelwright, S. (Eds.): Strategic Management of Technology and Innovation, 2nd ed.. Chicago: Irwin. 186-207.

Upton, D.M.; McAfee, A. (1996): The Real Virtual Factory. Harvard Business Review, 74, 4, 123-133.

Utterback, J.M. (1994): Mastering the Dynamics of Innovation. How Companies Can Seize Opportunities in the Face of Technological Change. Boston: Harvard Business School Press.

Van de Ven, A.; Angle, H.; Poole, M. (1989, Eds): Research on the Management of Innovation: The Minnesota Studies. New York: Ballinger/Harper\&Row.

von Boehmer, A.; Brockhoff, K.; Pearson, A.W. (1992): The Management of International Research and Development, in: Buckley, P.J.; Brooke, M.Z. (Eds.): International Business Studies, Oxford, 495-509.

von Zedtwitz, M. (2003a): A Four-Layer Model for Studying Organizational Structure. Academy of Management Best Papers Proceedings, Seattle, Aug 4-6, 2003.

von Zedtwitz, M. (2003b): Initial Directors of International R\&D Laboratories. $R \& D$ Management, Vol. 33, No. 4, 377-393.

von Zedtwitz, M.; Gassmann, O. (2002a): Market versus Technology Drive in R\&D Internationalization: Four different patterns of managing research and development. Research Policy, 31, 4, 569-588.

von Zedtwitz, M.; Gassmann, O. (2002b): Managing Customer Oriented Research. International Journal of Technology Management, 24, 2/3, 165-193.

Wheelwright, S.C.; Clark, K.B. (1992): Revolutionizing Product Development - Quantum Leaps in Speed, Efficiency, and Quality. New York: The Free Press.

Yin, R.K. (1994): Case Study Research: Design and Methods. Newbury Park, London: New Delphi. 